\title{
THE SOCIOLOGY OF TRANSLATION: OUTLINE OF AN EMERGING FIELD
}

\author{
Esperança Bielsa Mialet \\ Department of Sociology. University of Leicester
}

\begin{abstract}
This article explores the emerging field of the sociology of translation, focusing especially on two key areas: literary translation and news translation. While literary translation is a major area in translation studies, news translation has until recently received relatively little attention. It is argued that a sociological input to the study of both literary and news translation reveals not only important aspects of the social context in which translation occurs and contributes to a renewed understanding of the field, but also makes translation studies relevant to other disciplines, in particular sociology and globalisation research.
\end{abstract}

\section{Resum}

Larticle revisa el camp emergent de la sociologia de la traducció, amb un èmfasi especial en dues àrees clau: la traducció literària i la traducció periodística. Mentre que la traducció literària és un àmbit de gran importància en Traductologia, la traducció periodística ha rebut fins fa poc una atenció reduïda. Larticle planteja que introduir la sociologia en l'estudi de la traducció literària i periodística posa de relleu no tan sols aspectes importants del context social en el que es dóna la traducció i contribueix a una comprensió renovada del camp, sinó que també fa que la traducció esdevinga rellevant per a altres disciplines, en especial la sociologia i la recerca en globalització.

\section{Keywords}

Sociology of translation. Sociology of culture. Literary translation. News translation.

\section{Paraules clau}

Sociologia de la traducció. Sociologia de la cultura. Traducció literària. Traducció periodística. 
This article explores the emerging field of the sociology of translation, focusing especially on two key areas: literary translation and news translation. While literary translation is the oldest and one of the most fertile fields of inquiry in translation studies, news translation has until recently received relatively little attention. It is argued that a sociological input to the study of both literary and news translation reveals important aspects of the social context in which translation occurs that have remained largely unexamined, and helps to elucidate the function of translation in the global literary and news fields. A sociological perspective on translation also contributes to a renewed understanding of the discipline and makes translation studies relevant to other fields, in particular sociology and globalisation research.

Although the sociology of translation is a relatively new field, two different scholarly traditions have provided significant research in the area, especially in the last two decades. On the one hand, the discipline of translation studies (hereafter TS), which has increasingly come to adopt sociological approaches for the study of intercultural relations and, on the other, the work of a strand of French sociology influenced by Pierre Bourdieu's approach to the sociology of culture, which explicitly focuses on the social nature of translation and its place in the field of cultural production. Before giving an outline of this interdisciplinary field more fully, it is thus necessary to briefly introduce these perspectives and outline their relevance for a sociology of translation.

There is a significant body of writings on the practice of translation which go back to antiquity. However, TS is a recent discipline which emerged in the 1970s out of the field of applied linguistics. Of particular relevance for sociological approaches to translation is what has been termed the cultural turn in TS, which coincides with a major expansion of the discipline. The term "cultural turn" was first used in a collection of essays edited by Susan Bassnett and André Lefevere in 1990 entitled Translation, History, and Culture, to refer to a change in the object of study of TS away from a linguistic approach primarily devoted to translator training to a cultural studies approach, and is thus a markedly different development to what is known as the cultural turn in the social sciences, largely associated with postmodernism. In TS, the cultural turn signals a move away from textual concerns (primarily seen in 
terms of equivalence and faithfulness of the translation to the original text) towards wider cultural concerns and the study of how translations function in their cultures of destination, and towards notions of cultural manipulation, ideology and power. Consequently, it can be argued that the cultural turn makes TS an interdisciplinary field the focus of which is the study of cultural interaction (Bassnett and Lefevere 1998: 6).

In more recent years, this study has been characterised by the increasing use of sociological theories, especially those of Pierre Bourdieu, applied to translation. Thus, one of the leading journals in the discipline, The Translator, dedicated a special issue to the theme of "Bourdieu and the Sociology of Translating and Interpreting", published in 2005. In the same year, an international conference with the title "Translating and Interpreting as a Social Practice" was organised, with the aim of contributing to a conceptualisation of a general translation sociology. The selected outcomes of this conference have been published in an edited book entitled Constructing a Sociology of Translation (Wolf and Fukari 2007).

On the other hand, the almost total neglect of issues related to translation in British and American sociology contrasts with the increasing interest it has attracted in French sociology in recent years. A special issue of Actes de la recherche en sciences sociales, the journal founded by Bourdieu, on "Translation: International Literary Exchanges" was published in 2002. Research has been carried out on the nature of the profession and self-perception of literary translators, and on the social role of translation in international literary exchanges by scholars like Natalie Heinich, Gisele Sapiro, Johan Heilbron, Isabelle Kalinowski, and Pascale Casanova. Casanova herself has produced a historical account of the international literary field in which translation plays a key intermediary role, which will be discussed in detail in the first section of this article.

In both traditions, TS and French sociology of culture, research has predominantly been limited to literary translation. Recently, new research has been undertaken into the previously neglected major areas of news translation (Bielsa and Bassnett 2009; Cortés Zaborras and Hernández Guerrero 2005), localisation (Pym 2004) and ethnography (Sturge 2007), while the pivotal role of translation in the context of globalisation has also been tackled (Cronin 2003, 2006), and arguments for an enlargement of the discipline in response to global developments and power inequalities consistently formulated (Apter 2006; Tymoczko 2007). This article considers in detail two major areas of interest to the sociology of translation: literary translation, as its oldest, most established pursuit, and news translation, one of the newer 
areas that are developing fast in this interdisciplinary field. A last, concluding section inquires into the relevance of a sociological perspective on translation and what it can offer to the discipline of TS.

\section{A sociology of literary translation}

This section tackles book translation or literary translation ${ }^{1}$, which constitutes a small part of global information flows but is the area that has been more profusely researched in both TS and cultural sociology. As a preliminary point, two significant differences between literary translation and technical translation must be pointed out. Firstly, in literary translation, the author and the source text usually enjoy a sacralised position so that translations tend to be considered second order reproductions, devoid of originality and subservient to the original text. Secondly, literary translation implies the transfer of cultural capital, while so called technical translation is primarily viewed as a transfer of information. These two specific features of literary translation shape the nature of transnational literary exchanges in important ways. This will be analysed in detail in what follows.

Book translation expresses existing inequalities in information flows and the global dominance of English. British and American book production are characterised by a low number of translations. Since the 1950s, the number of translations into English has remained roughly between 2\% and 4\% of total book production, declining even further over the past decade. Translations accounted for just $1.4 \%$ of books published in 2001 in Britain and $2.07 \%$ of books published in 2004 in the United States (as compared, for example, with 22.9\% in 2002 in Italy or 7.3\% in 2004 in Germany). Conversely, since World War II, English has been the most translated language worldwide (Venuti 2008: 11). These figures give a clear view of what the dominance of AngloAmerican culture means: most countries receive a large number of English language book imports (as well as other cultural products such as films and television programmes), so that the presence of Anglo-American values in other cultures is high, while the UK and US are, in Venuti's words,

1. Literary translation refers in this context to translations published in books, whether they are of literary works or not, as opposed to technical translation (industry, publicity, news and media, etc.). This is Heinich's definition (1984: 264) and is also used by Kalinowski (2002: 48). However, others consider scientific translations to be technical translations. For instance, Venuti classifies translations from humanistic disciplines as literary, but scientific texts as technical translations (2008: 34). 
aggressively monolingual, unreceptive to foreign literatures, accustomed to fluent translations that invisibly inscribe foreign texts with British and American values and provide readers with the narcissistic experience of recognising their own culture in a cultural other. (Venuti 2008: 12)

Nevertheless, as Gayatri Spivak has remarked, the dominant position of English as a global language also implies a growing market for translations from non-European languages, as translated texts are often treated as a quick way to "know a culture" (2005: 94).

In a cultural field shaped by inequalities in global information flows and the prestige of dominant European literatures but, at the same time, by what Spivak considers "spurious and hyperbolic admiration" of certain non-European literatures, a general theorisation of the specific role of translation becomes a necessary means of explaining the nature of transnational cultural exchanges. In this context, Johan Heilbron conceives an emerging world-system of translation, pointing out that

Transnational cultural exchange is not simply the reflection of the structural contradictions in the world economy... Cultural exchanges have a dynamic of their own which is based on a certain autonomy vis-à-vis the constraints of the world market. (1999: 432)

However, the predominance of national literary histories and their focus on literary production narrowly conceived in terms of creation of original works to the exclusion of the significant role played by rewritings, has tended to obscure the import of these exchanges, both in quantitative and qualitative terms. In addition, a sociology of translation must be concerned with investigating its role in the transfer of cultural capital, which has until recently similarly been neglected in sociological accounts. Thus, in spite of his interest in the international circulation of ideas and of his very useful general remarks on the export of social theory (Bourdieu 2002, 1993b), Bourdieu omitted the role of translation in his account of the field of cultural production, which remained limited to a national context (1993a).

However, the central importance of international exchanges in the literary field has been explored in a book by Pascale Casanova entitled The World Republic of Letters (2004). In this pioneering work, the author undertakes to enlarge Bourdieu's account of the field of cultural production to the international context, showing that literatures are constituted relationally in a highly unequal international field. This perspective, which places transnational literary exchanges at the very centre, offers the most elaborate account of the role of translation in the cultural field to date. 
Casanova shows how the international literary field, which she calls the world republic of letters, was created in the $16^{\text {th }}$ century in the struggle of the vernaculars against the dominance of Latin and has since then expanded progressively. Its geography is based on the opposition of a literary capital, Paris, which represents the autonomous pole, and the regions which are dependent on it. It is thus a highly unequal structure. Inequalities are defined by linguistic and literary capital, or what she calls "literariness" - some languages are considered more literary than others and incarnate literature itself, while others, newcomers to the world republic of letters, have to fight for literary existence.

While literature is initially national, bound to language and to political and national institutions, there is, according to Casanova, a process of progressive autonomisation. Autonomous fields become denationalised, universal, and Paris acquires in the $19^{\text {th }}$ century a unique role, a power of universal consecration, becoming the capital of those who proclaim themselves nationless: the artists, and in particular it is the more autonomous writers from dominated national spaces who will seek exile in Paris. Indeed, following Casanova, the literary power of a central nation can be measured by the literary revolutions produced in its midst by peripheral writers who become universally recognised (her list is long and includes names like Faulkner, Joyce and Beckett, as well as numerous Latin American and African writers).

According to Casanova, Paris dominates the literary world, is the measure of literary modernity and consecrates the texts arrived from the peripheries. In this context, translation becomes an important element of valorisation and consecration of texts from the peripheries, and of diffusion of literary modernity from the centre to the margins, while translators are key cosmopolitan intermediaries - they export texts from one space to another whose literary value is established in the process. Casanova's achievement lies not just in demonstrating the significance of translation as an essential instrument of unification of the literary space, but also in distinguishing between the different functions that translation fulfils in this context (see 2004: ch. 4). Firstly, in the direction from centre to periphery, translation serves a basic function of capital accumulation: for poorer languages, it is a means of gaining capital, antiquity, nobility. Through translation the great universal texts are nationalised (as for example in German romantic translations of the classics of Greek and Roman antiquity, which served to challenge the centrality of French translations and opened a new status for German as a literary language). On the other hand, translation means the international diffusion of central literary capital and expresses the power of a language and a literature. 
In this context, translation can also serve as an instrument of "temporal acceleration", particularly in the struggle of the more autonomous writers (who are often polyglot and translators), in making possible the importation of the central norms and works that certify literary modernity to the periphery.

Secondly, Casanova is especially interested in a different function of translation in transfers from the periphery to the centre of the literary space, which she calls consecration or literarisation. Translation gives writers in dominated languages literary recognition, international existence, and also allows and reinforces the existence of an autonomous international position within their national field. For the dominant languages, it is a way of appropriating works from the peripheries. James Joyce, who was rejected in Dublin, ignored in London, prohibited in the US and consecrated in Paris is, in this context, her most obvious example.

An extreme case of dominated writers who have opted for central recognition are translated writers, a notion Casanova has borrowed from Salman Rushdie (1991: 17) to designate immigrant writers who have adopted the dominant tongue. Translated writers from disinherited literatures are torn by a structural contradiction that obliges them to choose between translation into a literary tongue that separates them from their national public but gives them artistic existence, and their reclusion in a "small" tongue that condemns them to invisibility or to a literary existence that is limited to their national literature. Translated writers, as figures caught in between highly unequal linguistic and literary exchanges, express in their biographies the contradictions of their global lives.

Casanova's account contrasts with a purely quantitative view of centrality based on the directionality of translation flows, such as Venuti's. Similarly, Heilbron, who has characterised the international translation system by its highly hierarchical structure and its unevenness, as well as by the firm dominance of English, has argued that the most central languages tend to have the lowest proportion of translations in their own book production (1999: 439; see also Heilbron and Shapiro 2007: 96). However, the quantitatively smaller, often neglected function of translation in consecrating peripheral texts is of key importance because, as Casanova demonstrates, it is in this form that the great literary revolutions that help to radically change the whole of the literary space take place. Significantly, while English is central in the first type of translations from the centre to the periphery, the low number of translations that are published as a percentage of total book production in English (as we have seen, less than 3\% both in Great Britain and the US) means that it plays a much more marginal role in consecrating peripheral texts (attracting mainly 
Commonwealth writers and thus having a role of regional rather than global importance), which ultimately undermines its centrality in the international literary field.

Perhaps then as a corrective both to overly quantitative views of translation flows and to Casanova's account, which is exclusively focused on the field of literature and the centrality of French, it can be productive to refer to sociological translations, a remarkably understudied field. Sociological translations, as a particular type of book translation, are a form of literary translation as defined above, but should arguably also be considered humanistic or literary translations in Venuti's sense. As such, they conform to the two general characteristics of literary translation highlighted at the beginning of this section: firstly, they tend to be perceived as secondary reproductions, subservient to the original text and author, rather than as creative works in their own right; secondly, sociological translations are fundamental for the transfer of cultural capital in the scientific field.

In contrast with the literary field, the sociological (and social scientific) field is characterised today by the unquestioned centrality of English. Following Casanova's argument, a measure of the central scientific power of the American and British academies is to be found in the scientific revolutions produced by peripheral scientists who have become universally recognised through English. Clear contemporary examples are Manuel Castells and Ulrich Beck. While Manuel Castells is a translated writer and it is highly unlikely that his influential The Information Age would have achieved the global impact it has if it had been written in one of his native languages (Catalan and Spanish) rather than English, Ulrich Beck's work gained international recognition only through its translation into English. Yet, beyond these famous names, the centrality of English in the social scientific field also rests on the thousands of relatively unknown researchers who ordinarily seek to publish their research in English in the most prestigious journals of the field, contributing to enhance the central scientific capital of these publications and, at the same time, seeking the international credentials that will advance their own positions in their national fields.

Sociological translations are an important part of the texts sociologists read, functioning, like literary rewritings, as originals in the scientific field (cf. Lefevere 1992). Most sociologists today have come into contact with classical sociological theory and with a significant part of contemporary theory only through translation, and rewritings are an important component of the intellectual history of sociology. However, very few studies of these sociological translations, which are often undertaken by sociologists, exist. Sociological 
rewritings, the conditions in which they are produced and their relationship with other forms of scholarly labour and with the sociological field at large have been marginalised in a culture that values originals and the sacrality of authorship. For example, as Uta Gerhardt notes, "the translation of Max Weber's classic The Protestant Ethic and the Spirit of Capitalism has never been dealt with as an achievement in its own right" (2007: 41). In spite of this lack of attention, Talcott Parsons' translation has achieved the status of a "classic" and is thus arguably an exception, but the fact that its significance has been silenced in accounts of Parsons' work ultimately corroborates the inferior status which sociological rewritings - as second-order reproductions, mere copies - are attributed. Yet, their study can shed light not only on particular texts and the transformations they undergo when they travel, but also on the nature of different academic fields from a comparative perspective and on the importance of the international dimension for the constitution of social theory.

Translations have a key role in introducing new ideas, concepts and perspectives into fields that can never be seen in isolation from a wider international context, and it is often foreign theory, circulated and made available in translation, which helps to challenge established positions and open the way to key innovations. At the same time, translations, by virtue of the transformations they undergo in different contexts, travel to places that are beyond the reach of originals, and must truly be considered not their extension but their afterlife, in Benjamin's sense. Therefore, to ignore the relevance of Parsons' Protestant Ethic as a translation, not only leads to a gap in the study of both Parsons' and Weber's work, but to fundamental misunderstandings regarding the way social theory travels across national fields.

Anglo-American sociology has been consistently blind to the important role translation plays in the discipline, both in mediating the international circulation of theory and in key methodological aspects of social research, a lack of interest that can in part be explained as a product of current global inequalities and the dominant position of the Anglo-American academy in the world. Sociologists have often undertaken translation as part of their scientific work. Yet, whether in the case of Parsons' classic version of Weber's The Protestant Ethic, or in less well know instances, such as David Frisby's translation of Simmel's Philosophy of Money or Eric Dunning's rendering of Elias' The Germans, this dimension of sociological work and its impact on the intellectual history of the discipline has remained largely unstudied.

The neglected significance of translation in the international circulation of theory serves to challenge the belief in symmetry and equal exchanges in 
global information flows and helps to shed new light on processes of (cultural) globalisation. In this context, translation - whether as capital accumulation or as consecration - appears as much more than a linguistic exchange and is revealed to fulfil basic functions in the transmission of cultural and scientific capital. A perspective that places translation at the centre serves to leave behind a national or comparatist angle and to assume a renewed understanding of the global circulation of both literature and social theory as based on highly unequal international exchanges which are essential in the constitution of the global literary and scientific fields.

\section{Initial steps for a sociology of news translation}

In contrast with literary translation, news translation is an area that until recently has received comparatively little attention. Translation studies has remained largely uninterested in textual practices that, to a great extent, tend to be carried out by journalists rather than translators. Media sociology has neglected the study of the linguistic processes that make it possible to produce and communicate news across geographic, cultural and linguistic boundaries. Yet, modern journalism is, since its very inception, global in scope, and has developed through the establishment of a global infrastructure for the production and circulation of news (for a historical account of the constitution of the modern journalistic field see Bielsa 2008; Bielsa and Bassnett 2009, ch. 3). Translation has, from the very beginning, been at the centre of global news production. The first news agency, Agence Havas (Agence FrancePresse's predecessor, founded in 1835), was initially created as a translation agency in 1832. Multilingual journalists played an important role in the establishment of worldwide networks for the production of news, at a time in which the telegraph helped to generate an unprecedented demand for foreign news in metropolitan centres. Today's popular image of the global journalist as a key agent of globalisation is derived from the classic figure of the foreign correspondent that by the end of the $19^{\text {th }}$ century was already fully established. Powerful news organisations - not just the news agencies, which became news wholesalers specialising in the production of raw news to be sold to other news organisations, but also prestigious newspapers like The Times - prided themselves on their foreign correspondents, and the coverage of international conflicts was established as an important news source, to be only matched in the second half of the $20^{\text {th }}$ century by other themes of global interest such as sport.

It is worthwhile asking ourselves about the reasons why TS has not devoted a great deal of attention to news translation in the past. The first of these is 
inevitably related to what I have already mentioned: the fact that it is mostly journalists rather than translators who are ordinarily engaged in news translation. An important feature of news translation is that it has been very successfully incorporated as an integral part of the production of news in major news organisations. Translation is seen as an important task of the journalist or news editor, who reshapes and edits information, making it ready for publication. It is generally believed in news organisations that only journalists - especially trained to respond to the journalistic criteria of news relevance and background knowledge of the target reader, and also to conform to the house style of the news organisation - are capable of successfully performing these tasks, and translation is not fundamentally perceived as any different from the editing of journalistic texts. This apparently seamless integration of translating news within the ordinary process of news production, together with a predominant textual practice based on fluency, which makes the translated text appear as if it was an original, is responsible for what I have referred to elsewhere as the double invisibility of news translation (Bielsa 2007: 151; Bielsa and Bassnett 2009: 72-3).

The second reason for ignoring news translation is that it does not fit very well with what until recently was still a fairly dominant view of translation based on equivalence as a central concern. News translation operates in fundamentally different ways than literary translation. In the first place, the sacrality of the author and of the original text, a product of the relative autonomy of the literary field, does not apply to the sphere of news. On the contrary: legal and organisational factors have traditionally determined that the news text is normally seen as a collective product, so that no single person is solely responsible for the shape and appearance of the final text. This refers not just to the fact that news texts are edited by people other than the journalists who originally wrote them; edited texts are usually also checked by a second pair of eyes and the same applies to translations. In addition, news translation responds to needs that are very different than those normally associated with the worldwide circulation of literary texts. A precondition for the successful transmission of news texts across geographical and linguistic boundaries is their thoroughgoing transformation so that, even if the news source is the same, the text can fully respond to the particularities of a new context in which the narrated events will impact in different ways. This explains why radical changes such as the full rewriting of titles and leads (first paragraphs), the restructuring of the order of paragraphs, and the addition and/or elimination of information are the norm rather than the exception in news translation. Moreover, in many cases, not even a single source text 
exists, and information is drawn for a number of sources and texts that are recombined to form a new unit. This process is not essentially dissimilar from what happens in the localisation industry, and has been adequately conceived by Anthony Pym, who argues that a localised text is not called to represent any previous text but it is rather part of a process of constant material distribution (2004: 5). Pym has also crucially maintained that "Translations are thus to be assessed as new texts designed to serve new purposes, without any necessary constraint by equivalence" (2004: 55).

With reference to current inequalities in global information flows, the central importance of English in the field of news must be qualified. The global dominance of English is echoed in the power of the two Anglo-American giants, Reuters and Associated Press, in the field of news. Only one other news agency, Agence France-Presse, is considered today a global player, but in terms of revenue it follows at a considerable distance from the other two. Moreover, in the field of television news, the dominance of the former two is even stronger, as there are today only two organisations of global significance: Reuters Television and Associated Press Television. Curiously, English seems to be established as the lingua franca in the global transmission of news images, which circulate exclusively with English language captions even in organisations like Agence France-Presse. The growing presence of English in organisational matters is also generally perceivable in non-English news agencies such as France-Presse and Inter Press Service, where it has progressively become the main language for coordinating operations at the international level. In terms of news markets and audiences, the global dominance of English is also favoured by current geopolitical imbalances. The US is today a pivotal source of news for any agency, and all the big players have sought to consolidate and expand their presence in the main news centres of Washington and New York. In some cases, such as that of France-Presse, this has led to a multilingual rather than monolingual composition, where French as well as Spanish language journalists work alongside their English counterparts in order to produce and distribute news from the US to their linguistically diverse audiences more efficiently. On the other hand, as France-Presse's case demonstrates, successfully penetrating the US market has become the key to establishing a global presence in the field of news, while the weight of English also increases with the agency's crucial expansion into the Asian news markets. This is what mainly distinguishes France-Presse from other important news agencies such as the Spanish EFE, which remain regional, rather than global, in scope. 
Nevertheless, the field of global news is also characterised by the central importance of the European news markets. This developed early on, in the second half of the $19^{\text {th }}$ century, when expanding worldwide telegraphic news went hand in hand with a growing appetite for the latest news in the metropolitan centres. It firmly established the field of news as a multilingual space. Thus, news wholesalers have traditionally produced newswires in the main European languages, including English, French, German, Spanish, Portuguese (the only addition to these is Arabic in the second half of the $20^{\text {th }}$ century), which are the languages of their most important consumers in quantitative terms. In the case of small European languages, translation is undertaken by national news organisations. Therefore, the fact that, very much like in the localisation industry, people consume news in their own language means that multilinguality is ensured and that translation will remain a fundamental practice in the production of news, drawing a complex map of practices at the local, regional and global levels.

The relevance of translation tends to be ignored or downplayed in accounts that emphasise present trends towards homogenisation and the increased importance of fewer and fewer sources in the field of global news. There is no doubt that Western news organisations have shaped the field of global news in major ways, successfully spreading the Western media model and Western values (ranging from objectivity and impartiality to the importance attributed to elites or to the topics and regions considered to be newsworthy), which have become hegemonic. It is also true that unprecedented privatisation, deregulation and commercialisation of media industries in recent decades has increased the influence of a few powerful organisations and made it no longer affordable for smaller ones to obtain their own sources. These factors have contributed to the homogenisation of news in important ways. Thus, for example, Oliver Boyd-Barrett states that "News agencies contribute to the homogenization of global culture in form and in source, while greatly multiplying the texts available within these standardized discourses" (1997: 143), while others emphasise the primacy of Anglo-American ideologies in the field of global news (Marchetti 2002; Paterson 1998).

However, it is also important to take into account translation's crucial intervention in obtaining news in situations that often imply interlingual transfer and the need to interpret and translate sources, as well as in producing news texts destined to reach diverse audiences in linguistic, geographical and cultural terms. Rather than taking translation for granted, in order to speak of homogenisation trends in the field of global news it is necessary to examine the way translation processes shape the nature of news and to assess the 
degree to which translation can be considered a form of violence in Venuti's sense, i.e. to what extent does translation serve to reduce the cultural other as the recognisable, the familiar or even the same, therefore completely domesticating the foreign text (2008: 14).

News translation is generally characterised by the primary objective of transmitting information to readers fast in a clear and effective way and by the need to conform to the prevailing style, rules and practices of the receiving language. As I have already mentioned, this entails a significant degree of transformation of the source text, which can be perceived in terms of thoroughgoing domestication. However, there is also the scope for a degree of foreignisation, or at the very least of hybridisation, which is implied by the impossibility of exact translation, the fact that no two languages have identical semantic and syntactic structures, and more generally by the necessity to adapt to the background knowledge and expectations of new target readers and to produce texts that can successfully function as news in different contexts. In addition, practices vary widely in different countries, types of media and news organisations. Close empirical analysis of news texts and the transformations they undergo through translation is therefore required in order to elucidate its role, and this often brings an extremely rich and unforeseen array of textual practices to light (see, for example, a detailed textual analysis of domesticating and hybridising translations in various accounts of Saddam Hussein's trial in British and European newspapers in Bielsa and Bassnett 2009, ch. 7). This diversity is an expression of the fact that, although we are increasingly watching, listening to and reading about the same events worldwide, a multitude of local versions and narratives of global events exists.

The study of translation in the field of news reveals the central importance of these ubiquitous but, at the same time, invisible processes that constitute an interconnected network of textual practices worldwide, and challenges overly mechanistic notions of Western dominance and trends towards the homogenisation of global news.

\section{Implications of a sociological perspective on translation: a change of paradigm?}

The third and last section of this article focuses on what a sociology of literary translation and a sociology of news translation have in common, in an attempt to elucidate what is specifically sociological about them and how this impacts on traditional conceptions of translation. It is argued that the sociology of translation involves a thoroughgoing change of perspective and thus a radical rethinking of prevailing paradigms in TS. Three main interrelated 
aspects of this proposed change of paradigm will be examined: firstly, the introduction of a global perspective that can account for literary and journalistic flows worldwide and challenge approaches that have tended to remain limited to the national level; secondly, an overcoming of the text versus context dichotomy that has prevailed in TS; thirdly, an incorporation of what is often referred to as the sociological imagination to the main aims and methodologies of TS.

Firstly, the most immediate consequence of examining both literary and news translation in terms of transnational exchanges and global information flows through a sociological perspective is a challenge to approaches that have tended to remain largely limited to a predominantly national and/or comparatist perspective. A sociological perspective implies a change of focus and reveals a completely new dimension of translation that only becomes visible at the global level. In this context, a useful tool has been the deployment of the sociological concepts of (world) system and/or field, and their application to the specific history of both literature and news. A traditional systemic approach puts the emphasis on the enduring structures that determine the behaviour of social agents, giving primacy to the functioning of social systems. From the 1970s, world systems theory introduced an international perspective to the systemic approach, focusing primarily on global inequality, perceived in terms of the relations that are established between an industrialised core and a dependent, exploited periphery. World systems theory has been applied to translation studies, most effectively by Heilbron, who presents a structural analysis of the international flows of translated books, explicitly seeking to account for both the unevenness of flows and the varying role of translations within different language groups (1999: 431). Significantly, as the author points out, it is only through the recognition of the global dimension that the role and nature of translation in local contexts can be adequately described:

The analysis of this world-system, and the position which various language groups occupy within it, is a precondition for understanding the role of translations in specific local or national contexts. The significance of translation within language groups, for example, is shown to depend primarily on the position of the language within the international system. (1999: 432)

On the other hand, the Bourdieusian notion of field has allowed the conceptualisation of the literary and the journalistic fields, among others, in terms of objective networks of positions, while also focusing on their specific historical development. If Bourdieu himself remained predominantly limited to a national perspective on the French cultural and educational fields, others 
have revealed the full potential of his notion of fields from a transnational perspective. Casanova's analysis of the function of translation in the international literary field has been commented upon above in some detail. A perspective that places translation at the centre serves to leave behind a national or comparatist angle and to assume a renewed understanding of the global circulation of literature as based on highly unequal international exchanges, which are essential in the constitution of the global literary field. Similarly, a sociological perspective reveals the importance of translation practices in the field of global news, a space marked not only by global asymmetries and the power of a small number of big organisations but also, at the same time, by the multiplicity of texts available.

Secondly, and intimately related with the first point, sociological approaches and concepts such as those of system and field have also fundamentally challenged the traditional dichotomy of text versus context that has tended to predominate in TS. Since the cultural turn, issues of power, manipulation and ideology started to become central in the discipline, in a clear move away from exclusively textual concerns towards wider cultural concerns. However, this had the effect of reinforcing, rather than eliminating, the text versus context dichotomy, with the danger of falling into somewhat rigid descriptions of texts and their contexts, which could be seen as two separate realms. Sociology's focus on social structures and their effects on agents' actions abolishes this dichotomy by placing a new emphasis on the empirical study of translation practices and the institutional arrangements that regulate them, and on the varying role and function of translation in different language groups and/or cultural contexts. Sociology thus seeks to account for the situation or context within which the text acquires its meaning. However, sociology must also address the textual dimension if it is to avoid falling into a reductionist, sociologistic explanation of which it sometimes has been rightly accused. In other words, a systemic approach must incorporate a dimension of textuality. Perhaps the best, still unsurpassed model for such an undertaking is the work of Theodor Adorno, which seeks to describe how the social has crystallised in the text, and of which his essays on lyric poetry, where a hidden collective current is shown to underlie the most individualistic and detached lyric subject, and on Kafka are excellent examples (Adorno 1991, 1967).

Thirdly and finally, perhaps the most significant contribution that sociology can make to the study of translation, beyond certain concepts or theoretical and methodological orientations, is what the sociologist and public intellectual Wright Mills once called the sociological imagination. Not limited to 
sociology as an academic discipline and sometimes well developed in other areas such as journalism, fiction and history, the task and promise of the sociological imagination is, according to Wright Mills, the understanding of history and biography, and of the relationship between the two within society:

The sociological imagination enables its possessor to understand the larger historical scene in terms of its meaning for the inner life and the external career of a variety of individuals. (2000: 5 , originally published in 1959)

It is this intersection between biography and history that ultimately allows us to grasp the most intimate aspects of our lives in connexion with wider social realities and to situate ourselves historically in our times, so as to better cope with and to orient ourselves in the rapidly changing world in which we live. This constituted for Wright Mills the cultural value of the social sciences in contemporary society, once the limitations of highly specialised technological means have become widely perceivable, as a form of self-consciousness and of pursuit of more general intellectual interests. This is also what sociology has to offer to the study of translation.

\section{References}

ADORNO, Theodor W. (1967) "Notes on Kafka" (S. Weber \& S. Weber, Trans.). In: Prisms. London: Spearman. pp. 243-271.

Adorno, Theodor W. (1991) "On Lyric Poetry and Society" (S. W. Nicholsen, Trans.). In: Adorno, T. W. (ed.) Notes to Literature (Vol. 1). New York: Columbia University Press. pp. 37-54.

APTER, Emily. (2006) The Translation Zone. Princeton \& Oxford: Princeton University Press.

BASSNETt, Susan \& André Lefevere (eds.) (1990) Translation, History and Culture. New York: Pinter.

BASSNETT, Susan \& André Lefevere. (1998) Constructing Cultures. Essays on Literary Translation. Clevedon: Multilingual Matters.

BIELSA, Esperança. (2007) "Translation in Global News Agencies". Target, 19: 1. pp. 135-155.

BIELSA, Esperança. (2008) "The Pivotal Role of News Agencies in the Context of Globalization: A Historical Approach". Global Networks 8: 3. pp. 347-366.

BIELSA, Esperança \& Susan Bassnett. (2009) Translation in Global News. London and New York: Routledge.

Bourdieu, Pierre. (1993a) The Field of Cultural Production (R. Johnson, Trans.). Cambridge: Polity Press. 
BOURDIEU, Pierre. (1993b) "Concluding Remarks: For a Sociogenetic Understanding of Intellectual Works". In: Calhoun, Craig; Edward LiPuma \& Moishe Postone (eds.) Bourdieu: Critical Perspectives. Cambridge: Polity. pp. 263-275.

BOURDIEU, Pierre. (2002) "Les conditions sociales de la circulation internationale des idées". Actes de la Recherche en Sciences Sociales 145. pp. 3-8.

BOYD-BARRETT, Oliver. (1997) "Global News Wholesalers as Agents of Globalization”. In: Sreberny-Mohammadi, A.; D. Winseck; J. McKenna \& O. Boyd-Barrett (eds.), Media in Global Context. A Reader. London: Arnold. pp. 131-144.

Casanova, Pascale. (2004) The World Republic of Letters (M. B. DeBevoise, Trans.). Cambridge, Mass.: Harvard University Press.

CORTÉs ZABORRAS, Carmen \& María José Hernández Guerrero (eds.) (2005) La traducción periodística. Cuenca: Ediciones de la Universidad de Castilla-La Mancha.

Cronin, Michael. (2003) Translation and Globalization. London \& New York: Routledge.

Cronin, Michael. (2006) Translation and Identity. London \& New York: Routledge.

GerhardT, U. (2007) "Much More than a Mere Translation - Talcott Parsons's Translation into English of Max Weber's Die protestantische Ethik und der Geist des Kapitalismus: An Essay in Intellectual History". Canadian Journal of Sociology 32: 1. pp. 41-62.

HeILBRON, Johan. (1999) "Towards a Sociology of Translation: Book Translations as a Cultural World-System". European Journal of Social Theory 2: 4. pp. 429-444.

HeILBRON, Johan \& Giselle Sapiro. (2007) "Outline for a Sociology of Translation. Current Issues and Future Prospects”. In: Wolf, Michaela \& Alexandra Fukari (eds.) 2007. pp. 93-107.

HEINICH, Natalie. (1984) "Les traducteurs littéraires: l'art et la profession". Revue française de sociologie XXV, pp. 264-280.

KALINOWSKI, Isabelle. (2002) "La vocation au travail de traduction". Actes de la recherche en sciences sociales 144. pp. 47-54.

LEFEVERE, André. (1992) Translation, Rewriting and the Manipulation of Literary Fame. London \& New York: Routledge.

Marchetti, Dominique. (2002) "Linternationale des images". Actes de la Recherche en Sciences Sociales 145. pp. 71-83.

PATERSON, Chris. (1998) "Global Battlefields". In: Boyd-Barrett, O. \& T. Rantanen (eds.) The Globalization of News. London, Thousand Oaks, New Delhi: Sage. pp. 79-103.

PyM, Anthony. (2004) The Moving Text: Localization, Translation, and Distribution. Amsterdam/ Philadelphia: John Benjamins.

RuSHDIE, Salman. (1991) Imaginary Homelands. London: Granta Books. 
SPIVAK, Gayatri C. (2005) "Translating into English". In: Bermann, S. \& M. Wood (eds.) Nation, Language, and the Ethics of Translation. Princeton: Princeton University Press. pp. 93-110.

Sturge, Kate. (2007) Representing Others. Translation, Ethnography and the Museum. Manchester: St. Jerome Publishing.

TyмосzKo, Maria. (2007) Enlarging Translation, Empowering Translators. Manchester \& Kinderhook: St. Jerome Publishing.

Venuti, Lawrence. (2008) The Translator's Invisibility: A History of Translation. Second edition. London: Routledge.

Wolf, Michaela, \& Alexandra Fukari (eds.) (2007) Constructing a Sociology of Translation. Amsterdam \& Philadelphia: John Benjamins.

Wright Mills, C. (2000) The Sociological Imagination. Oxford: Oxford University Press. 